\title{
EFFICIENCY OF EXPENDITURES AND THE ECONOMIC SIZE OF FARMS IN POLAND
}

\author{
Sławomir KOCIRA ${ }^{\mathbf{1}}$, Anna KOCIRA ${ }^{\mathbf{2}}$, Agnieszka SZPARAGA ${ }^{\mathbf{3}}$, \\ Pavol FINDURA ${ }^{4}$, Anna KRAWCZUK ${ }^{1}$ \\ ${ }^{1}$ Department of Machinery Exploitation and Management of Production Process, University of Life \\ Sciences in Lublin, POLAND \\ ${ }^{2}$ State School of Higher Education in Chełm, Institute of Agricultural Sciences, POLAND \\ ${ }^{3}$ Koszalin University of Technology, Department of Agrobiotechnology, POLAND \\ ${ }^{4}$ Slovak University of Agriculture in Nitra, Department of Machines and Production Biosystems, \\ SLOVAKIA \\ E-mail of corresponding author: slawomir.kocira@up.lublin.pl
}

Keywords: FADN, work expenditures, total expenditures, economic efficiency

\begin{abstract}
This study analyzed the efficiency of various types of expenditures such as human labor, energy, total, and expenditures in farms which are classified into six groups based on their economic size. Analysis was performed during the period 2004-2015 for farm holdings from the entire area of Poland, and those participating in the Farm Accountancy Data Network. It was determined, that the total efficiency has a decreasing tendency in all holding groups. Both the holdings with the lowest as well as largest economic size in case of turbulence in financial markets (e.g., the financial crisis of 2007 2009 ) obtain the total expenditure efficiency below 1 . The efficiency of human labor expenditures has a tendency to increase through the entire period of analysis for the largest holdings. The direct expenditures are most efficiently used in the smallest holdings, and they are slightly over 50\% higher than in the largest holdings.
\end{abstract}

\section{INTRODUCTION}

The basic task for a farm holding is to generate (obtain) income to ensure the maintenance of the farmer's family. The level of income largely depends on the scale and structure of production in a holding (Sobierajewska, 2015; Skarżyńska 2011). However, holdings with similar area of arable land (AR) often vary in terms of the income generated. As observed by Niezgoda (2009), the profitability of farms in Poland is highly diverse (Niezgoda 2009). These differences stem from the management method of a holding, which often depends on its size. One of the indicators of the farm holding size is the agricultural lands (AL), animal stock and the economic size of the farm. The economic size influences the modernization possibilities of farm holdings (Kołtun et al. 2015). One of the economic measures of farm holding management efficiency includes the management efficiency indexes. Values of these indexes are relatively low in Poland. This state is influenced by the excessive employment and low average surface of the holdings. Also, the overload of the holdings with fixed assets has a negative effect on the management efficiency (Malaga-Toboła et al. 2015; Wasilewski and Wasilewska 2008). The economic size of a holding is used to determine its economic viability (Szelagg-Sikora 2009). Considering the above information, it appears viable to perform an efficiency analysis for the expenditures in holdings with different economic sizes.

\section{MATERIALS AND METHODS}

The study material originates from the Farm Accountancy Data Network (FADN). The study included approximately 1200 individual farm holdings, for which data was collected within Polish FADN. The analysis covered results of holding operations in the period of 2004-2015. 
The Polish FADN is a system of collecting and using accountancy data from farm holdings. It was created based on the Act on Collecting and Using Accountancy Data from Farm Holdings of 29 November 2000 (Journal of Laws 2001, No. 3, item 20 with later amendments). It functions within the European system of collecting and using accountancy data.

In general, the efficiency measure is the ratio between the effect and its cause, which is the labor and financial expenditure in economic terms. For labor, the measure of efficiency was assumed as the relationship between the value of total agricultural production and the human labor, energy, total, and direct expenditures.

The human labor expenditure efficiency was calculated based on the following formula:

$$
E_{P L}=\frac{P_{O}}{N_{P}}
$$

$E_{P L}-$ Efficiency of human labor expenditures $\left(€ \cdot \mathrm{man} \mathrm{h}^{-1}\right)$

$P_{O}-$ Total production $\left(€ \cdot\right.$ hold $\left.^{-1}\right)$

$N_{P}$ - Human labor expenditure (man h $\cdot$ hold. $^{-1}$ )

The energy expenditure efficiency was calculated based on the following formula:

$$
E_{E}=\frac{P_{O}}{N_{E}}
$$

$E_{E}-$ Efficiency of energy expenditures incurred $\left(€ \cdot €^{-1}\right)$

$N_{E}$ - Energy expenditures $\left(€ \cdot\right.$ hold. $\left.^{-1}\right)$

The total expenditure efficiency was calculated based on the following formula:

$$
E_{O}=\frac{P_{O}}{N_{O}}
$$

$E_{O}-$ Efficiency of total expenditures $\left(€ \cdot €^{-1}\right)$

$N_{O}-$ Total expenditures $\left(€ \cdot\right.$ hold $\left.^{-1}\right)$

The direct expenditures efficiency was calculated based on the following formula:

$$
E_{B}=\frac{P_{O}}{N_{B}}
$$

$E_{B}-$ Efficiency of direct expenditures $\left(€ \cdot €^{-1}\right)$

$N_{B}$ - Direct expenditures, $\left(€ \cdot\right.$ hold. $\left.^{-1}\right)$

The economic size of the holding shall be determined on the basis of the total standard output of the holding. It shall be expressed in euro. The method of calculating the economic size of the holding and the economic size classes shall be as set Commission Regulation (EC) No 1242/2008.

The economic size of a holding is measured as the total standard output of the holding expressed in Euro. Holdings are classified by size classes, the limits of which are set out below.

1 - from 2000 to less than $8000 €$,

2 - from 8000 to less than $25000 €$,

3 - from 25000 to less than $50000 €$,

4 - from 50000 to less than $100000 €$, 
5- from 100000 to less than $500000 €$, 6 - above $50000 €$.

\section{RESULTS}

The total production in the tested period per one ha of AL in the tested holding groups was variable, which increased in the largest holdings and decreased in the smallest holdings (Figure 1). A decrease in production occurred in all groups in 2009.

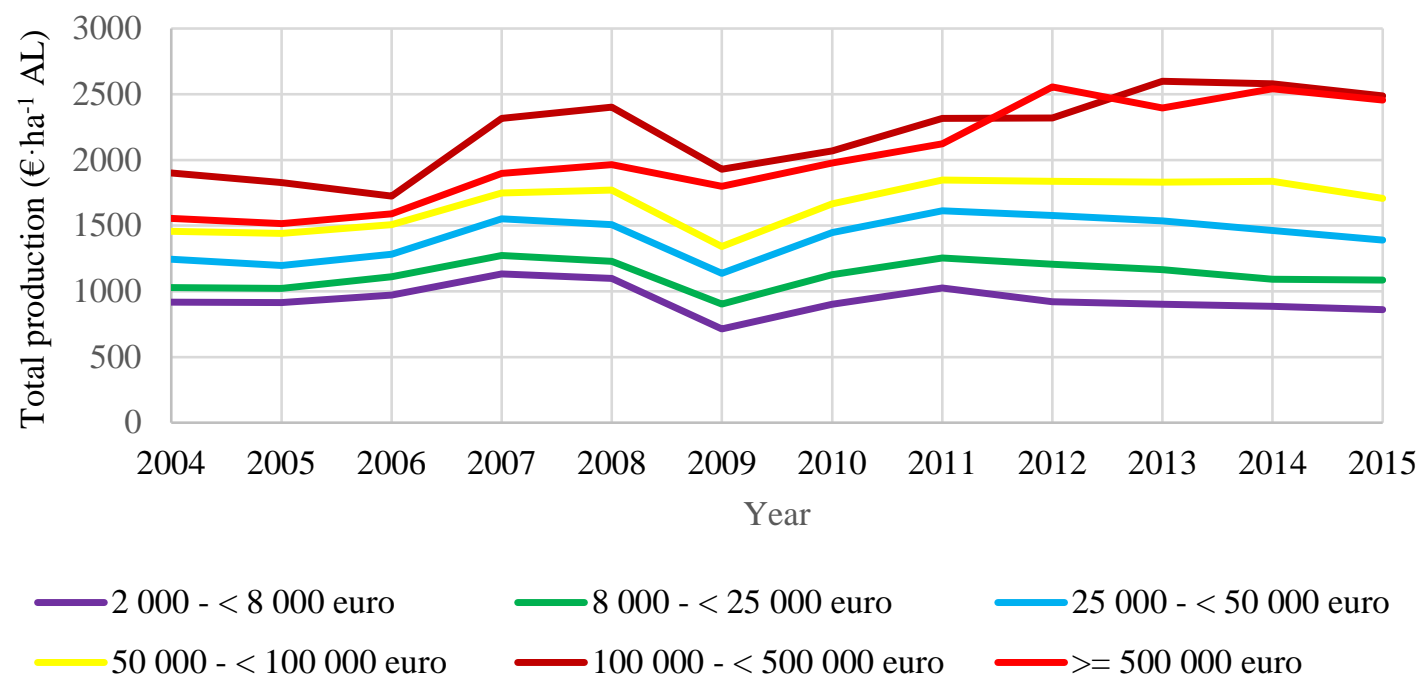

Figure 1. Total production in individual holding groups during 2004-2015.

Similar to the total production, in the groups with the lowest economic size a decrease in the labor expenditures (in man $\mathrm{h} / \mathrm{ha} \mathrm{AL}$ ) was observed. In the remaining groups, the expenditures were subjected to minor fluctuations (Figure 2).

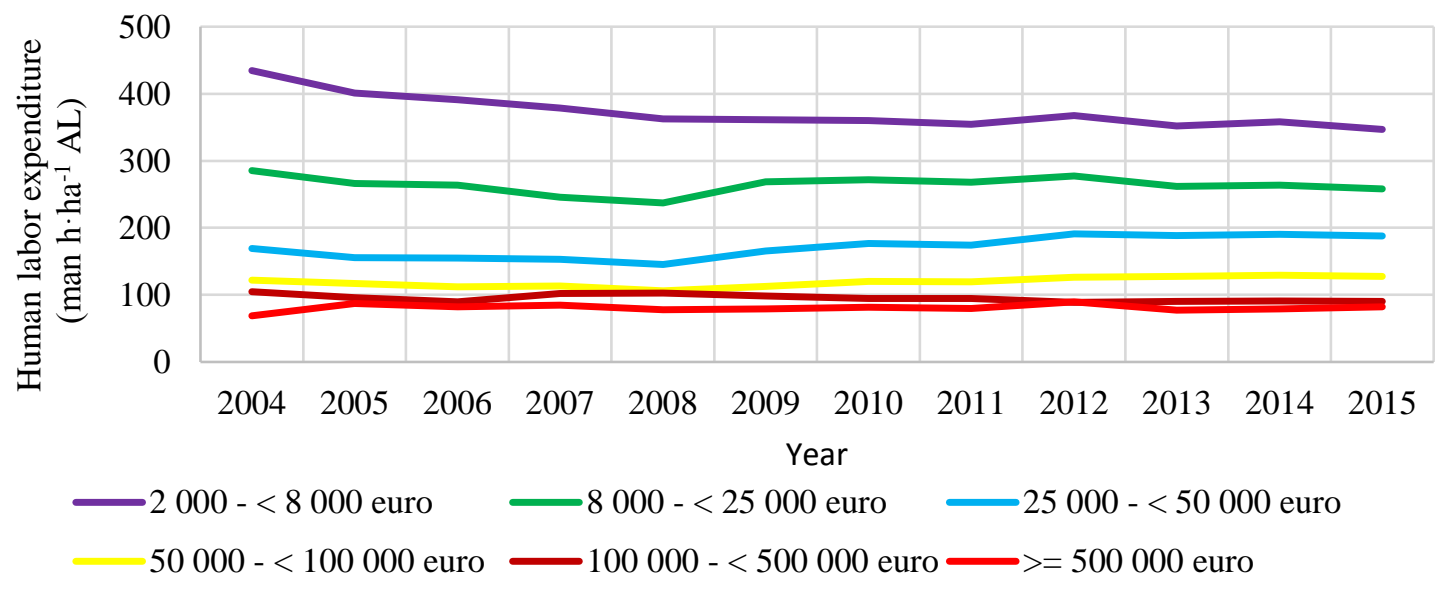

Figure 2. Labor expenditures in individual holding groups during 2004-2015.

The efficiency of human labor expenditures in holdings with economic size ranging from 100,000 to $500,000 €$ in the tested period increased from $18.2 € \cdot \mathrm{man}^{-1}$ to 27.5 $€ \cdot \operatorname{man}^{\mathrm{h}-1}$. Also in the holdings with the economic size exceeding $500,000 €$ a $32 \%$ increase of efficiency of human labor expenditures was observed. In the remaining groups of holdings, the value of the index in the tested period remained at a similar level. In 2009, a clear decrease of efficiency of labor expenditures can be seen caused 
by the decrease of the total production value. The global financial crisis influenced the total production value.

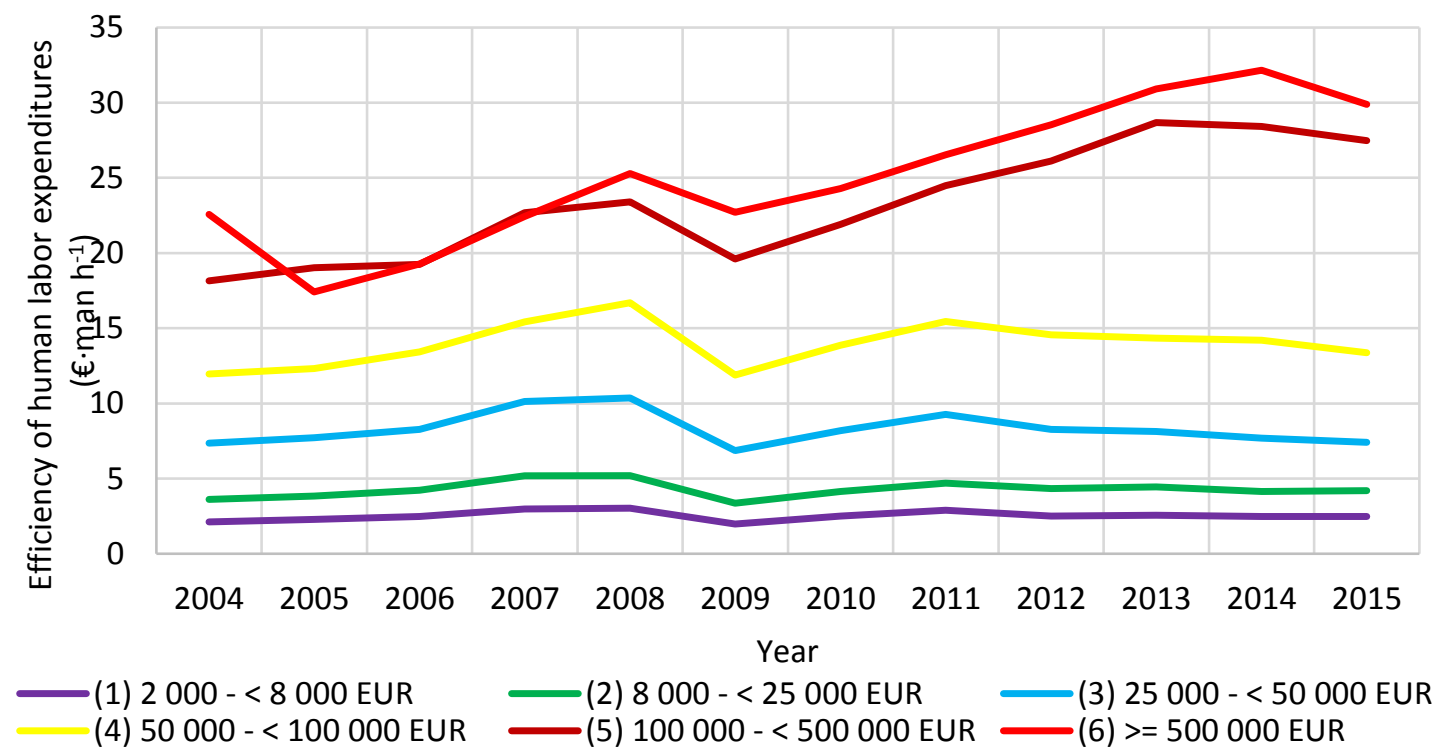

Figure 3. Efficiency of labor expenditures in individual holding groups during 2004-2015.

The efficiency of energy expenditures in years 2004-2015 decreased in all holding groups (Figure 4). This was probably caused by the substitution of human labor with objectified labor, as the proceeding mechanization of agricultural activities is linked to the simplification of production technologies, resulting in increased energy expenditures in the production processes. In the last analyzed year (2015) an increase in the efficiency of energy expenditures was observed in all holding groups, however, this increase had begun in the largest holdings in 2013.

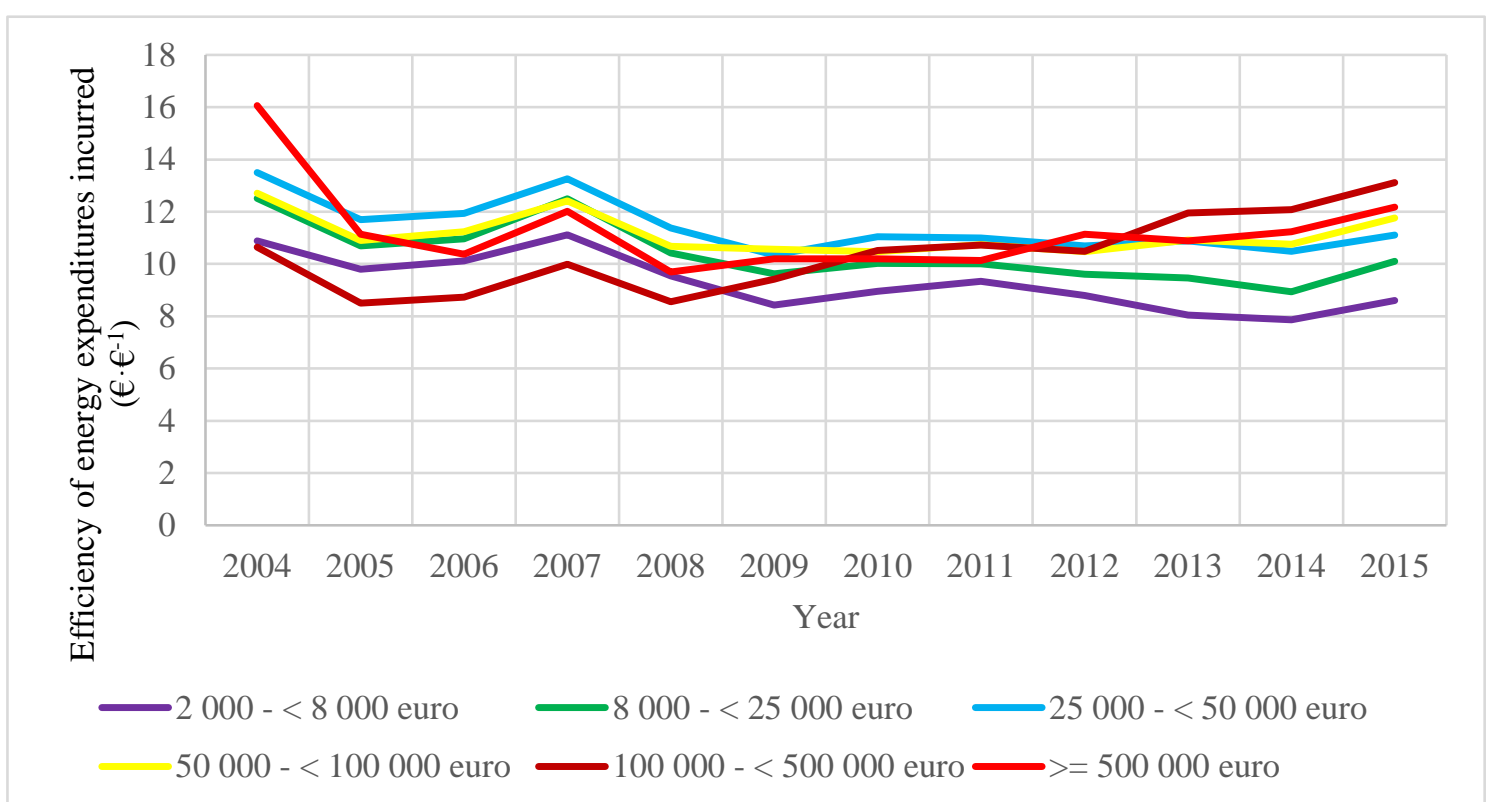

Figure 4. Efficiency of energy expenditures in individual holding groups during 2004-2015.

Unfortunately, one of the most important measures of efficiency (efficiency of total expenditures) had a decreasing tendency in all studied holding groups (Figure 5). In extreme cases, it attained a value below 1, indicating higher expenditures than the 
obtained sales income. The highest efficiency was exhibited by the holdings ranging from 25,000 to $100,000 €$. The observed tendency of decreasing efficiency of total expenditures indicates that the increase of expenditures for production is higher than the increase of production value. During the period of the financial crisis (2008-2010), a dramatic decrease of expenditure efficiency was observed in all tested holding groups.

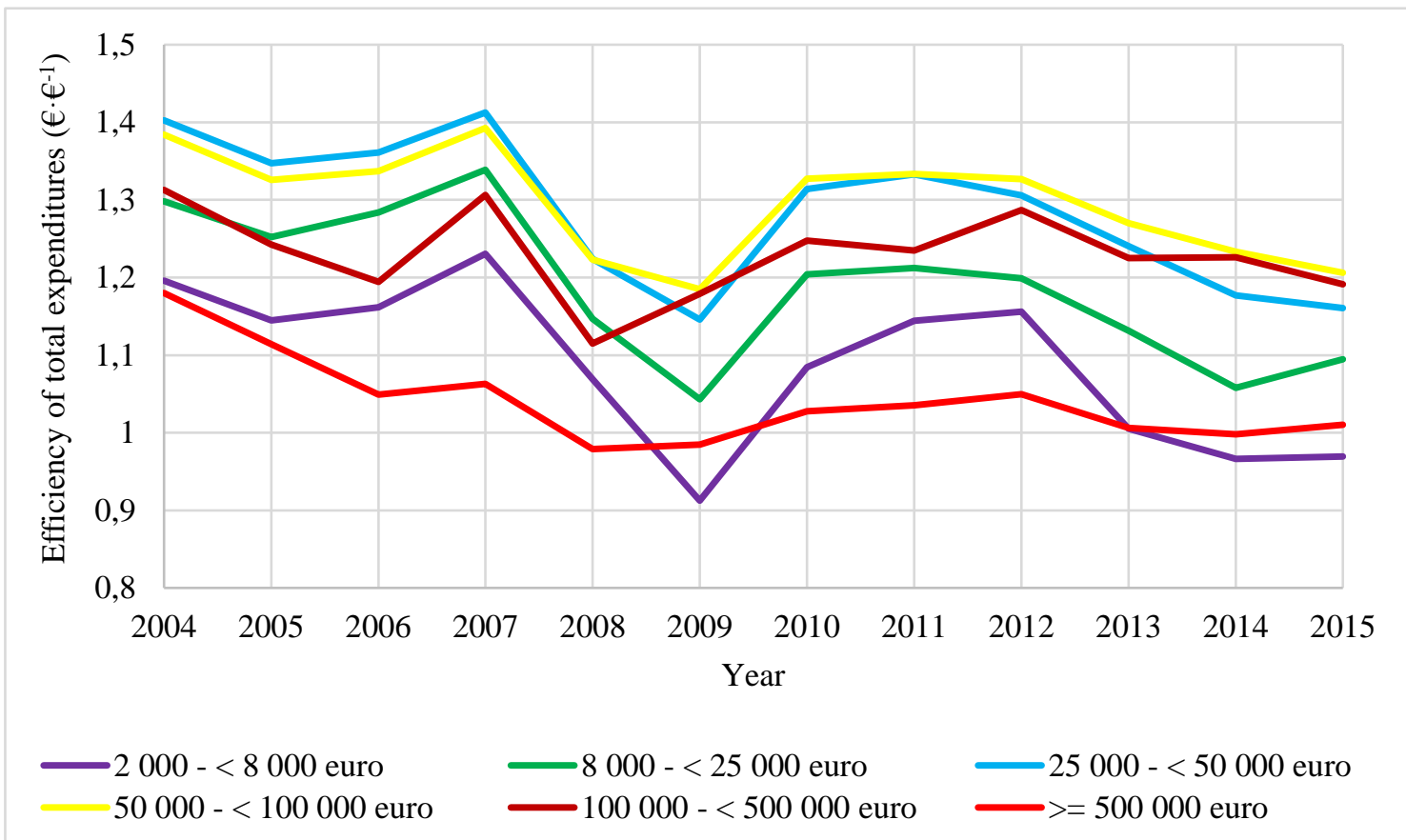

Figure 5. Efficiency of total expenditures in individual holding groups during 2004-2015.

The index for direct expenditures efficiency remained at a constant level for all groups in the studied period. Only the smallest holdings indicated high variability of the index (Figure 6).

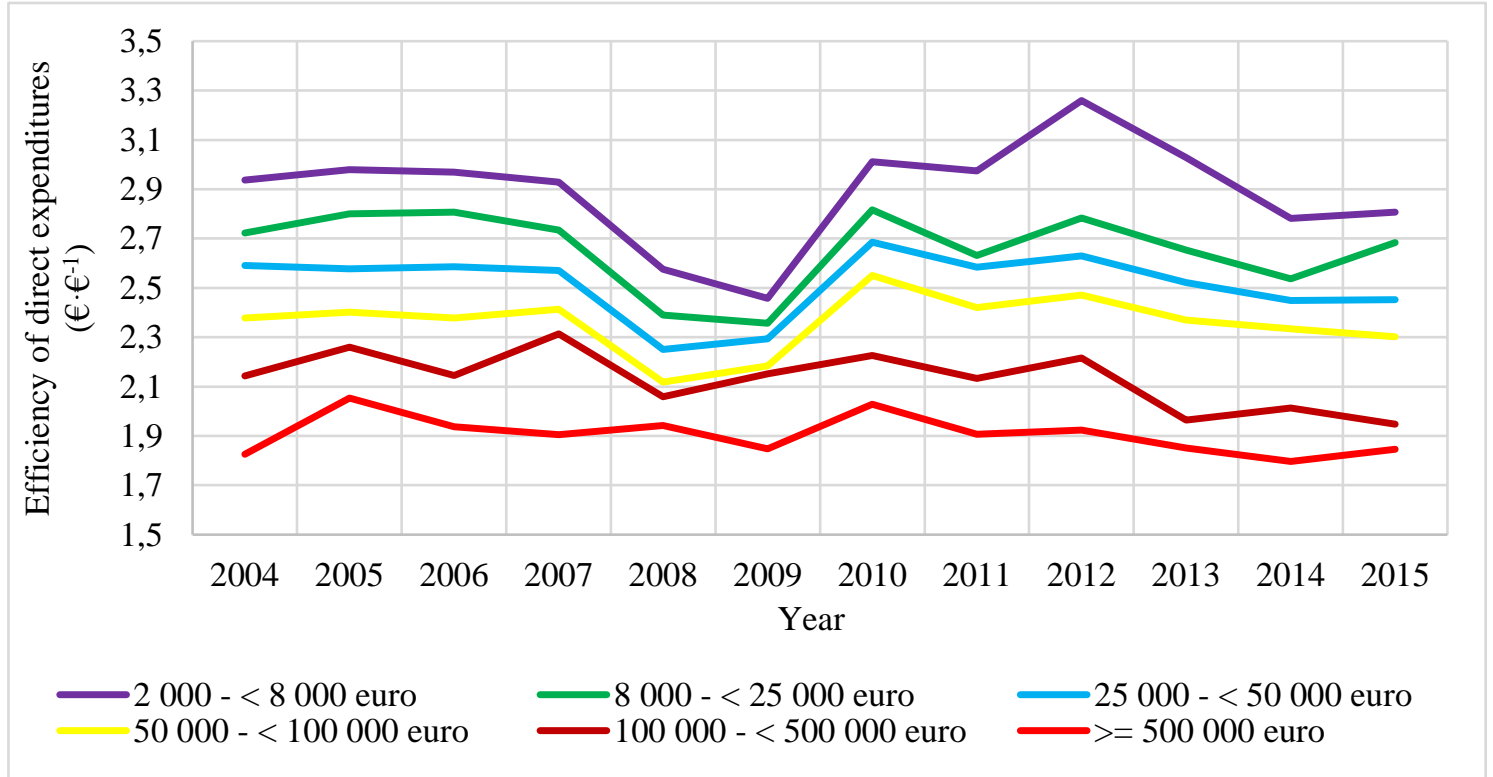

Figure 7. Efficiency of direct expenditures in individual holding groups during 2004-2015. 


\section{CONCLUSIONS}

The conducted analysis of total production and efficiency of expenditures in holdings grouped according to their economic size has demonstrated that the total production in the period 2004-2015 per ha AL increased at the highest rate in large and very large holdings, whereas the economically weakest holdings are characterized by the highest labor expenditures per ha AL.

Both the holdings with the lowest and the largest economic size, during turbulence in financial markets (e.g., the financial crisis of 2007-2009) obtain the total expenditure efficiency below 1 .

It was determined that labor expenditure efficiency increased during the first 4 years after Polish access to the EU structure. In the subsequent analyzed years, the efficiency increased only in the large and very large holdings.

It was observed that the efficiency of total expenditures has a decreasing tendency. It is an alarming signal as it influences the profitability of farm holdings.

The efficiency of direct expenditures in individual groups remained at a constant level. Only during the latest financial crisis (2007-2009), a decrease of efficiency of these expenditures took place.

The direct expenditures are most efficiently used in the smallest holdings, and they are slightly over $50 \%$ higher than in the largest holdings.

\section{REFERENCES}

Sobierajewska J. (2015). Changes in the structure of production and the efficiency of farms. Roczniki Naukowe Stowarzyszenia Ekonomistów Rolnictwa i Agrobiznesu 17(5), 258-263.

Niezgoda D. (2009). Determinants of profitability of agricultural holdings diversified in respect of their economic size. Roczniki Nauk Rolniczych 96 (4), 155-165.

Kołtun M., Kocira S., Krzysiak Z., Ćwiklińska M., Kocira A., \& Koszel M. (2015). Economic size and developmental possibilities of chosen family farms in Poland. Agriculture and Agricultural Science Procedia 7, 113 - 118. DOI:10.1016/j.aaspro.2015.12.003

Malaga-Toboła U., Tabor S., \& Kocira S. (2015). Productivity of resources and investments at selected ecological farms. Agriculture and Agricultural Science Procedia 7, 158-164.

DOI:10.1016/j.aaspro.2015.12.011

Wasilewski M., \& Wasilewska A. (2008). Equipage and effectiveness of making use of real capital assets in agricultural enterprises. Zeszyty Naukowe SGGW Ekonomika i organizacja gospodarki żywnościowej 66, 49-62.

Szeląg-Sikora A. (2009). Economic life-span of farms versus possession of engineering means of production. Inżynieria Rolnicza 1(110), 311-318.

Skarżyńska A. (2011). The scale of agricultural production activities and their profitability. Roczniki Nauk Rolniczych 98(1), 7-21. 